\title{
Need for a safe vaccine against respiratory syncytial virus infection
}

Joo-Young Kim, PhD, Jun Chang, PhD

Division of Life \& Pharmaceutical Sciences, College of Pharmacy, Ewha Womans University, Seoul, Korea
Received: 13 March 2012, Accepted: 15 May 2012

Corresponding author: Jun Chang, PhD

Division of Life \& Pharmaceutical Sciences, College of Pharmacy, Ewha Womans University, 52 Ewhayeodae-gil, Seodaemun-gu, Seoul 120-750, Korea

Tel: +82-2-3277-2549, Fax: +82-2-3277-3051

E-mail: tcell@ewha.ac.kr

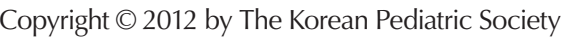

Human respiratory syncytial virus (HRSV) is a major cause of severe respiratory tract illnesses in infants and young children worldwide. Despite its importance as a respiratory pathogen, there is currently no licensed vaccine for HRSV. Following failure of the initial trial of formalin-inactivated virus particle vaccine, continuous efforts have been made for the development of safe and efficacious vaccines against HRSV. However, several obstacles persist that delay the development of HRSV vaccine, such as the immature immune system of newborn infants and the possible Th2-biased immune responses leading to subsequent vaccine-enhanced diseases. Many HRSV vaccine strategies are currently being developed and evaluated, including live-attenuated viruses, subunit-based, and vector-based candidates. In this review, the current HRSV vaccines are overviewed and the safety issues regarding asthma and vaccine-induced pathology are discussed.

Key words: Respiratory syncytial viruses, Vaccines, Asthma, Pathology

This is an open-access article distributed under the terms of the Creative Commons Attribution Non-Commercial License (http://creativecommons.org/licenses/by$\mathrm{nc} / 3.0 /$ ) which permits unrestricted non-commercial use, distribution, and reproduction in any medium, provided the original work is properly cited.

\section{Introduction}

Since its first discovery in the 1950s, human respiratory syncytial virus (HRSV) has been recognized as the leading viral pathogen of severe respiratory tract diseases in infants and young children. HRSV causes yearly epidemics, and it is estimated that HRSV infection results in hospitalizations of $>3$ million children under 5 years of age ${ }^{1)}$. Most children are infected during the first year of life, all are infected by age 3 , and recurrent infections occur throughout life, possibly due to incomplete RSV immunity ${ }^{2}$. An increased incidence of asthma has been also associated with severe HRSV infection in the lower respiratory tract ${ }^{3}$. HRSV also causes severe diseases in the elderly that are associated with comparable mortality as influenza ${ }^{4)}$.

HRSV is a member of Paramyxoviridae family of the non- segmented negative-strand RNA viruses. HRSV could be divided into 2 antigenic subgroups, $A$ and $B$, according to their reactive patterns to monoclonal antibodies. These subtypes co-circulate, and the predominance of 1 subtype over the other seems to vary by year and location. The RSV genome contains genes for 11 proteins, including transmembrane proteins $\mathrm{G}, \mathrm{F}$, and $\mathrm{SH}$. G and F are the only HRSV proteins that induce neutralizing antibodies ${ }^{5,6)}$. The antigenic diversity of HRSV is mainly associated with the amino acid heterogeneity of $\mathrm{G}$ protein, in which homology comparison shows only $-53 \%$ identity between the A and B subgroups ${ }^{7}$. Recent evidence demonstrated that the recombinant adenovirus-based vaccine-expressing $\mathrm{G}$ protein of subtype A perfectly protects immune mice from HRSV challenge of a related subtype $\mathrm{A}$ isolate but only partially protects mice from HRSV challenge with the B isolate 
subtype $^{8)}$. These results suggest that the protective efficacy of $\mathrm{G}$ protein-based HRSV vaccine over $2 \mathrm{HRSV}$ subtypes depends on the sequence employed in the vaccine.

Animal models for HRSV infection and disease are indispensible in the research of prophylactic vaccines and novel therapies for HRSV disease. Animal models also provide links between tissue culture studies and early stage human trials. An ideal model should reproduce all aspects of HRSV disease in humans, such as clinical signs of illness, relevant pathological alterations, and susceptibility to viral replication. Chimpanzees are the most appropriate model to fit the criteria and are primarily used for vaccine studies; however, economical and ethical burdens restrict their use in HRSV research. As such, rodent models are the most common animal model for HRSV study. The cotton rat has become a standard rodent animal for studying HRSV disease since it is semi-permissive for HRSV replication and shows some clinical signs of HRSV disease. Inbred laboratory mice have been the most popular animal for experimental HRSV infection and disease, although they are less susceptible to viral replication and show limited symptoms and signs of the illness. The availability of numerous genetically modified strains and mousespecific tools make this species the most popular animal model for HRSV research.

\section{HRSV infection and asthma}

Neonates with HRSV infection are more susceptible to diseases such as bronchiolitis, interstitial pneumonitis, and alveolitis. Structural immaturity of the respiratory system and an underdeveloped immune system may contribute to HRSV infection severity. Several cohort studies suggested that HRSV infection in the lower respiratory tract of infants is closely connected to later development of asthma. A prospective cohort study in Finland demonstrated that severe bronchiolitis requiring hospitalization in infancy was a significant risk factor for asthma that extends into adolescence $^{9}$. In a study in Sweden, hospitalization for HRSV bronchiolitis in the first year of life was the significant risk factor for asthma and allergy patterns in patients at $>18$ years of age ${ }^{10}$. Another study also demonstrated relevance between HRSV severity and the development of asthma in a cohort of $>95,000$ infants ${ }^{11)}$.

In a mouse model, it was shown that 1- or 3-week-old age groups could provoke increased airway hyperresponsiveness (AHR) after primary RSV infection ${ }^{12)}$. However, when the infected mice were later re-exposed to the RSV, the initial RSV infection at 1 week of age resulted in enhanced AHR, mucus production, and airway eosinophilia compared with the initial RSV infection of weanling mice ${ }^{12)}$. Due to the failure of the formalin-inactivated RSV (FI-RSV) vaccine in 1969, it has been proposed that an understanding of the immune system of infants is very important for both the treatment of severe HRSV infection and vaccine development ${ }^{13}$. Throughout these studies, it is thought that the age of initial HRSV infection is one of the important factors of severity of viral infection-associated bronchiolitis and is a strong predictor of the development of asthma.

Pre-existing allergic symptoms such as genetic tendencies and prior exposure to an allergen can lead to increased Th2-dominant immune responses against HRSV infection. Several genetic studies in cytokines reported that HRSV-induced respiratory disease and asthma share genetic factors ${ }^{14}$. Polymorphisms in the chemokine receptor 5, interleukin (IL)-4, IL-10, IL-13, and transforming growth factor $\beta \beta$ genes were associated with HRSV-associated bronchiolitis severity. Some environmental risk factors such as daycare attendance, the presence of siblings, passive smoke exposure, and allergic sensitization to foods during the first years of life are important in the association between HRSV infection and asthma ${ }^{15)}$. Makela et al. ${ }^{16)}$ revealed that prior airway exposure to ovalbumin increases HRSVinduced AHR and the accumulation of Th2 cytokine-producing T lymphocytes, granulocytes (eosinophils and neutrophils), and CD8+ T cells in the lungs.

Severity of HRSV infection in early life is associated with an increased production of Th 2 cytokines, which could influence the later immune response to inhaled pathogens ${ }^{17)}$, and reduced and delayed interferon (IFN)- $\gamma$ responses ${ }^{18)}$. Han et al. ${ }^{19)}$ demonstrated that HRSV infection in the neonatal stage resulted in reduced IFN- $\gamma$ production compared with infection in the weanling or adult stage as well as the development of AHR and goblet cell hyperplasia in a mouse model. When re-infected with RSV later, the sequelae such as enhanced AHR, increased IL-13 production associated with mucus hyperproduction, and eosinophilia were worsened. The role of IFN- $\gamma$ in the severity of RSV-mediated respiratory disease is not yet well defined. However, the relationship between IFN- $\gamma$ production and pulmonary sequelae suggests that IFN- $\gamma$ plays an important role in deciding the lesion of RSV-mediated disease.

The production of a viral pathogen-specific immunoglobulin (Ig) is an important event in host defense against virus infection. In earlier studies in the HRSV field, most investigators were concerned with antibodies of the $\operatorname{IgA}, \operatorname{IgG}$, and $\operatorname{IgM}$ isotypes in nasopharyngeal secretions during HRSV infection. They suggested that these Igs bound to RSV-infected cells ${ }^{20}$. Since Welliver et al. ${ }^{3)}$ reported about RSV-specific IgE in 1981, several studies have proved the existence of RSV-specific IgE in infants and children with severe HRSV infection-induced disease ${ }^{21-24)}$. In these studies, they consistently demonstrated that HRSV-infected patients with wheezing had higher titers of virus-specific IgE than patients infected with HRSV who 
did not have wheezing. Furthermore, HRSV-specific IgE was highly correlated with HRSV infection severity. In a mouse model, it was proven that the production of RSV-specific IgE is highly correlated with the development of RSV-mediated wheezing and post-allergentriggered asthma ${ }^{25,26)}$. However, it is unclear how HRSV leads to upregulation of virus-specific $\operatorname{IgE}$ production in both infected humans and mice.

The basic feature, effector functions, and roles of eosinophils have been studied in various disease states. Most researchers believe that eosinophils are major pathophysiological mediators in respiratory disease and asthma ${ }^{27)}$. Likewise, eosinophils have been considered end-stage effector cells in asthma and other respiratory disease like HRSV infection. However, it is not well known whether eosinophils are directly responsible for the immunopathology induced by HRSV infection, play an unexpected role in the host immune system, or are simply bystander cell phenotypes ${ }^{28)}$. On the other hand, some investigators argue that eosinophils show a protective effect in various diseases. If major functions of eosinophils are harmful to the host, the cell types will not consistently persist.

Eosinophils have secretory ribonuclease that can directly affect the single-stranded RNA genome of $\mathrm{RSV}^{27)}$. Phipps et al. ${ }^{29)}$ investigated RSV clearance in wild-type and eosinophil-enriched IL-5 transgenic mice and suggested that RSV clearance proceeded more efficiently in the IL-5 transgenic mice. Although HRSV infection is associated with pulmonary eosinophilia, eosinophils have not been clearly linked to the HRSV-mediated progression to asthma either mechanistically or pathophysiologically. It has also not been proven that eosinophils promote virus clearance. A further study is needed to clarify how eosinophils are involved in the sequelae of HRSV infection.

\section{Immunopathology involved in vaccination and subsequent HRSV infection}

The infected individual induces a broad range of immune responses to clear the HRSV infection, but these immune responses are also known to contribute to the clinical manifestations of HRSV diseases. Antibody responses have been proven sufficient to prevent or restrict the primary infection as evidenced by palivizumab, a humanized monoclonal antibody that is currently used as a passive prophylaxis against HRSV infection in high-risk populations ${ }^{30)}$. However, once RSV infection is established, T-cell responses are required to completely eliminate the virus ${ }^{31)}$. $T$ cells also play important roles in pulmonary inflammation, in which cytokines secreted by $\mathrm{T}$ cells provoke severe lung pathology marked by a massive infiltration of immune cells ${ }^{32)}$.

In the initial trial of the FI-RSV vaccine in the late 1960s, the vaccine proved to be poorly protective against but rather enhance HRSV disease severity ${ }^{33)}$. Although the mechanism of this vaccineinduced disease enhancement remains not completely understood, it is proposed that FI-RSV induces unusual antibody responses with little neutralizing activity compared with that induced by natural HRSV infection ${ }^{34)}$. Subsequent studies demonstrated that FI-RSV induced imbalanced Th2-type CD4 T-cell responses in experimental animal models ${ }^{35-37)}$. Thus, vaccine-enhanced disease following vaccination appears to be associated with massive pulmonary inflammation initiated by vaccine-primed Th2-type CD4 T cells.

G glycoprotein, the major RSV attachment protein, is thought to be an important protective antigen against RSV infection ${ }^{38)}$. The central domain of $\mathrm{G}$ protein is relatively conserved between strains and subtypes and contains several protective B-cell epitopes ${ }^{39-41)}$. Numerous studies have suggested that priming with $G$ protein is associated with the induction of a polarized Th2-type response similar to that induced by FI-RSV, which leads to pulmonary eosinophilia upon RSV challenge of G-immunized mice ${ }^{39,42-45)}$. However, in the presence of an immunodominant cytotoxic T lymphocyte (CTL) epitope from M2 protein, G protein-primed mice did not develop pulmonary eosinophilia during HRSV challenge ${ }^{46)}$. Thus, it is likely that the absence of a Th1-promoting effect of RSV-specific CTLs, rather than the $\mathrm{G}$ protein itself, is responsible for the Th2-biased response. It has recently been suggested that $\mathrm{G}$-specific immune responses are not solely the basis for vaccine-enhanced illness and should not be excluded from potential vaccine strategies ${ }^{47-49)}$. Based on these findings, it should be emphasized that the fine balance between protective immunity and vaccine-induced immunopathology is one of the most important issues to be considered in the development of safe HRSV vaccines.

\section{Current strategies for the development of HRSV vaccine}

Since the most serious HRSV disease occurs at 2 to 7 months of age, immunization should be started within the first few weeks of life. However, several major obstacles must be overcome to enable the development of a pediatric HRSV vaccine. First, the immune system of young infants is relatively immature compared to that of older children and adults. As such, HRSV vaccines targeting the newborn population should be immunogenic enough to induce protective immunity in a relatively immature immune environment. Second, maternal antibodies might interfere with the actions of administered vaccines, especially in the first few weeks of life ${ }^{50)}$. To ensure vaccination success, it might be necessary for effective vaccines to avoid the compromising activity of maternal antibodies. Third, the 
failure of the early vaccine trial with FI-RSV significantly increased the safety standards for HRSV vaccines, which could be associated with detrimental vaccine-enhanced illness. Thus, new vaccine candidates should be thoroughly verified to have little vaccineassociated pathology and illness.

Various approaches have been applied in the development of effective HRSV vaccines. One of the major strategies for HRSV vaccine is the use of live-attenuated RSV strains for intranasal administration that mimic natural infection. Several live-attenuated HRSV vaccine candidates have been developed by conventional cold passage methods and subsequently evaluated in several clinical stages $^{51,52)}$. A second-generation live-attenuated HRSV has been also generated by reverse genetics (rA2cp strains) and tested in HRSVnaïv 1- to 2-month-old infants, and protective immunity could be achieved in a majority of the vaccine recipients ${ }^{53,54)}$. However, for this live-attenuated HRSV platform, it is quite challenging to determine whether the balance between over- and under-attenuation is most appropriate for a safe and effective vaccine.

Due to the potential for disease exacerbation, the use of inactivated or subunit vaccines had been considered inappropriate in the pediatric population. However, several HRSV-derived proteins and their derivatives as recombinant subunit vaccines have been evaluated in preclinical and clinical stages. Purified $F$ and $G$ proteins from HRSVinfected mammalian cells and $\mathrm{F} / \mathrm{G}$ chimeric proteins produced in insect cells generated humoral responses similar to those observed in FI-RSV vaccination in rodent models ${ }^{55,56)}$. However, the use of appropriate adjuvants was shown to enhance the immunogenicity of subunit vaccines ${ }^{57,58)}$.

Another subunit vaccine, $\mathrm{BBG} 2 \mathrm{Na}$, which consists of a $\mathrm{G}$ protein region covering amino acids 130 to 230 and the albumin-binding domain of streptococcal protein $\mathrm{G}$, has also been evaluated in preclinical and clinical testing ${ }^{59,60)}$. BBG2Na was well tolerated in phase II studies, but the trial was stopped due to a limited number of unexpected adverse events ${ }^{(1)}$.

Viral vectored vaccines employing platforms such as the vaccinia virus $^{6}$, adenovirus ${ }^{49,(2,63)}$, Sendai virus ${ }^{64)}$, and parainfluenza virus ${ }^{65)}$, have been developed and evaluated as HRSV vaccine candidates. Most of these candidates exhibited significant immunogenicity and protective immunity in animal models, showing the possibility of further development. Other forms of vaccines using replicon-based non-replicating viral vectors or virus-like particles ${ }^{66,67}$, live bacteria ${ }^{68)}$, and avian virus ${ }^{69)}$ have been also reported to be immunogenic and induce varying degrees of protective immunity in mouse studies. Vaccination of DNA plasmids expressing $\mathrm{F}$ or $\mathrm{G}$ protein has shown only a limited degree of protection against HRSV challenge ${ }^{70,711}$.

\section{Conclusion}

For many years, the development of an HRSV vaccine has been a high priority in many public health agendas. As mentioned above, numerous vaccine strategies have been tested or are being tested for further development. Needless to say, basic research into RSV virology and immunology will provide important information in vaccine development. Once we understand the enigmatic immune evasion and immunopathology of HRSV more clearly, we will be able to advance the development of HRSV vaccines. More serious awareness of the social and economical burden of HRSV diseases must also occur. We are hopeful that our great efforts into HRSV vaccine development will soon achieve the goal of safe and effective vaccines in the near future.

\section{Acknowledgment}

This work was supported by grant R15-2006-020 from the National Core Research Center program of the Ministry of Science $\&$ Technology and the Korea Science \& Engineering Foundation through the Center for Cell Signaling \& Drug Discovery Research at Ewha Womans University.

\section{References}

1. Nair H, Nokes DJ, Gessner BD, Dherani M, Madhi SA, Singleton RJ, et al. Global burden of acute lower respiratory infections due to respiratory syncytial virus in young children: a systematic review and meta-analysis. Lancet 2010;375:1545-55.

2. Hall CB, Walsh EE, Long CE, Schnabel KC. Immunity to and frequency of reinfection with respiratory syncytial virus. J Infect Dis 1991;163:6938.

3. Welliver RC, Wong DT, Sun M, Middleton E Jr, Vaughan RS, Ogra PL. The development of respiratory syncytial virus-specific IgE and the release of histamine in nasopharyngeal secretions after infection. N Engl J Med 1981;305:841-6.

4. Falsey AR, Hennessey PA, Formica MA, Cox C, Walsh EE. Respiratory syncytial virus infection in elderly and high-risk adults. N Engl J Med 2005;352:1749-59.

5. Walsh EE, Hall CB, Briselli M, Brandriss MW, Schlesinger JJ. Immunization with glycoprotein subunits of respiratory syncytial virus to protect cotton rats against viral infection. J Infect Dis 1987;155:1198-204.

6. Connors M, Collins PL, Firestone CY, Murphy BR. Respiratory syncytial virus (RSV) F, G, M2 (22K), and N proteins each induce resistance to RSV challenge, but resistance induced by $\mathrm{M} 2$ and $\mathrm{N}$ proteins is relatively short-lived. J Virol 1991;65:1634-7.

7. Johnson PR, Spriggs MK, Olmsted RA, Collins PL. The G glycoprotein of human respiratory syncytial viruses of subgroups $A$ and $B$ : extensive sequence divergence between antigenically related proteins. Proc Natl Acad Sci U S A 1987;84:5625-9. 
8. Jang JE, Lee JB, Kim KH, Park SM, Shim BS, Cheon IS, et al. Evaluation of protective efficacy of respiratory syncytial virus vaccine against $\mathrm{A}$ and $\mathrm{B}$ subgroup human isolates in Korea. PLoS One 2011;6:e23797.

9. Piippo-Savolainen E, Remes S, Kannisto S, Korhonen K, Korppi M. Asthma and lung function 20 years after wheezing in infancy: results from a prospective follow-up study. Arch Pediatr Adolesc Med 2004;158:10706.

10. Sigurs N, Aljassim F, Kjellman B, Robinson PD, Sigurbergsson F, Bjarnason R, et al. Asthma and allergy patterns over 18 years after severe RSV bronchiolitis in the first year of life. Thorax 2010;65:1045-52.

11. Wu P, Dupont WD, Griffin MR, Carroll KN, Mitchel EF, Gebretsadik T, et al. Evidence of a causal role of winter virus infection during infancy in early childhood asthma. Am J Respir Crit Care Med 2008;178:1123-9.

12. Dakhama A, Park JW, Taube C, El Gazzar M, Kodama T, Miyahara N, et al. Alteration of airway neuropeptide expression and development of airway hyperresponsiveness following respiratory syncytial virus infection. Am J Physiol Lung Cell Mol Physiol 2005;288:L761-70.

13. Kim HW, Canchola JG, Brandt CD, Pyles G, Chanock RM, Jensen K, et al. Respiratory syncytial virus disease in infants despite prior administration of antigenic inactivated vaccine. Am J Epidemiol 1969;89:42234.

14. Singh AM, Moore PE, Gern JE, Lemanske RF Jr, Hartert TV. Bronchiolitis to asthma: a review and call for studies of gene-virus interactions in asthma causation. Am J Respir Crit Care Med 2007;175:108-19.

15. Copenhaver CC, Gern JE, Li Z, Shult PA, Rosenthal LA, Mikus LD, et al. Cytokine response patterns, exposure to viruses, and respiratory infections in the first year of life. Am J Respir Crit Care Med 2004; 170:175-80.

16. Makela MJ, Tripp R, Dakhama A, Park JW, Ikemura T, Joetham A, et al. Prior airway exposure to allergen increases virus-induced airway hyperresponsiveness. J Allergy Clin Immunol 2003;112:861-9.

17. van der Sande MA, Kidd IM, Goetghebuer T, Martynoga RA, Magnusen A, Allen S, et al. Severe respiratory syncytial virus infection in early life is associated with increased type 2 cytokine production in Gambian children. Clin Exp Allergy 2002;32:1430-5.

18. Culley FJ, Pollott J, Openshaw PJ. Age at first viral infection determines the pattern of T cell-mediated disease during reinfection in adulthood. J Exp Med 2002;196:1381-6.

19. Han LL, Alexander JP, Anderson LJ. Respiratory syncytial virus pneumonia among the elderly: an assessment of disease burden. J Infect Dis 1999;179:25-30.

20. McIntosh K, McQuillin J, Gardner PS. Cell-free and cell-bound antibody in nasal secretions from infants with respiratory syncytial virus infection. Infect Immun 1979;23:276-81.

21. Aberle JH, Aberle SW, Dworzak MN, Mandl CW, Rebhandl W, Vollnhofer G, et al. Reduced interferon-gamma expression in peripheral blood mononuclear cells of infants with severe respiratory syncytial virus disease. Am J Respir Crit Care Med 1999;160:1263-8.

22. Bui RH, Molinaro GA, Kettering JD, Heiner DC, Imagawa DT, St Geme JW Jr. Virus-specific IgE and IgG4 antibodies in serum of children infected with respiratory syncytial virus. J Pediatr 1987;110:87-90.

23. Rabatic S, Gagro A, Lokar-Kolbas R, Krsulovic-Hresic V, Vrtar Z, Popow-Kraupp T, et al. Increase in CD23+ B cells in infants with bronchiolitis is accompanied by appearance of $\operatorname{IgE}$ and $\operatorname{IgG} 4$ antibodies specific for respiratory syncytial virus. J Infect Dis 1997;175:32-7.

24. Russi JC, Delfraro A, Borthagaray MD, Velazquez B, García-Barreno
B, Hortal M. Evaluation of immunoglobulin E-specific antibodies and viral antigens in nasopharyngeal secretions of children with respiratory syncytial virus infections. J Clin Microbiol 1993;31:819-23.

25. Dakhama A, Lee YM, Ohnishi H, Jing X, Balhorn A, Takeda K, et al. Virus-specific IgE enhances airway responsiveness on reinfection with respiratory syncytial virus in newborn mice. J Allergy Clin Immunol 2009;123:138-145.e5.

26. Dakhama A, Park JW, Taube C, Chayama K, Balhorn A, Joetham $\mathrm{A}$, et al. The role of virus-specific immunoglobulin $\mathrm{E}$ in airway hyperresponsiveness. Am J Respir Crit Care Med 2004;170:952-9.

27. Rosenberg HF, Dyer KD, Domachowske JB. Eosinophils and their interactions with respiratory virus pathogens. Immunol Res 2009;43:12837.

28. Rosenberg HF, Dyer KD, Domachowske JB. Respiratory viruses and eosinophils: exploring the connections. Antiviral Res 2009;83:1-9.

29. Phipps S, Lam CE, Mahalingam S, Newhouse M, Ramirez R, Rosenberg HF, et al. Eosinophils contribute to innate antiviral immunity and promote clearance of respiratory syncytial virus. Blood 2007;110:1578-86.

30. Johnson S, Oliver C, Prince GA, Hemming VG, Pfarr DS, Wang SC, et al. Development of a humanized monoclonal antibody (MEDI-493) with potent in vitro and in vivo activity against respiratory syncytial virus. J Infect Dis 1997;176:1215-24.

31. Graham BS, Bunton LA, Wright PF, Karzon DT. Role of T lymphocyte subsets in the pathogenesis of primary infection and rechallenge with respiratory syncytial virus in mice. J Clin Invest 1991;88:1026-33.

32. Alwan WH, Record FM, Openshaw PJ. CD4+ T cells clear virus but augment disease in mice infected with respiratory syncytial virus. Comparison with the effects of CD8+ T cells. Clin Exp Immunol 1992;88:52736.

33. Kapikian AZ, Mitchell RH, Chanock RM, Shvedoff RA, Stewart CE. An epidemiologic study of altered clinical reactivity to respiratory syncytial (RS) virus infection in children previously vaccinated with an inactivated RS virus vaccine. Am J Epidemiol 1969;89:405-21.

34. Murphy BR, Walsh EE. Formalin-inactivated respiratory syncytial virus vaccine induces antibodies to the fusion glycoprotein that are deficient in fusion-inhibiting activity. J Clin Microbiol 1988;26:1595-7.

35. Waris ME, Tsou C, Erdman DD, Zaki SR, Anderson LJ. Respiratory synctial virus infection in $\mathrm{BALB} / \mathrm{c}$ mice previously immunized with formalin-inactivated virus induces enhanced pulmonary inflammatory response with a predominant Th2-like cytokine pattern. J Virol 1996;70: 2852-60.

36. De Swart RL, Kuiken T, Timmerman HH, van Amerongen G, Van Den Hoogen BG, Vos HW, et al. Immunization of macaques with formalininactivated respiratory syncytial virus (RSV) induces interleukin13-associated hypersensitivity to subsequent RSV infection. J Virol 2002;76:11561-9.

37. Connors M, Giese NA, Kulkarni AB, Firestone CY, Morse HC 3rd, Murphy BR. Enhanced pulmonary histopathology induced by respiratory syncytial virus (RSV) challenge of formalin-inactivated RSV-immunized $\mathrm{BALB} / \mathrm{c}$ mice is abrogated by depletion of interleukin-4 (IL-4) and IL-10. J Virol 1994;68:5321-5.

38. Taylor G, Stott EJ, Bew M, Fernie BF, Cote PJ, Collins AP, et al. Monoclonal antibodies protect against respiratory syncytial virus infection in mice. Immunology 1984;52:137-42.

39. Sparer TE, Matthews S, Hussell T, Rae AJ, Garcia-Barreno B, Melero $\mathrm{JA}$, et al. Eliminating a region of respiratory syncytial virus attachment 
protein allows induction of protective immunity without vaccineenhanced lung eosinophilia. J Exp Med 1998;187:1921-6.

40. Martinez I, Melero JA. Enhanced neutralization of human respiratory syncytial virus by mixtures of monoclonal antibodies to the attachment (G) glycoprotein. J Gen Virol 1998;79( Pt 9):2215-20.

41. Bastien N, Trudel M, Simard C. Complete protection of mice from respiratory syncytial virus infection following mucosal delivery of synthetic peptide vaccines. Vaccine 1999;17:832-6.

42. Johnson TR, Johnson JE, Roberts SR, Wertz GW, Parker RA, Graham BS. Priming with secreted glycoprotein $G$ of respiratory syncytial virus (RSV) augments interleukin-5 production and tissue eosinophilia after RSV challenge. J Virol 1998;72:2871-80.

43. Openshaw PJ, Clarke SL, Record FM. Pulmonary eosinophilic response to respiratory syncytial virus infection in mice sensitized to the major surface glycoprotein G. Int Immunol 1992;4:493-500.

44. Hancock GE, Speelman DJ, Heers K, Bortell E, Smith J, Cosco C. Generation of atypical pulmonary inflammatory responses in BALB/c mice after immunization with the native attachment $(\mathrm{G})$ glycoprotein of respiratory syncytial virus. J Virol 1996;70:7783-91.

45. Tebbey PW, Hagen M, Hancock GE. Atypical pulmonary eosinophilia is mediated by a specific amino acid sequence of the attachment $(\mathrm{G})$ protein of respiratory syncytial virus. J Exp Med 1998;188:1967-72.

46. Srikiatkhachorn A, Braciale TJ. Virus-specific CD8+ T lymphocytes downregulate $\mathrm{T}$ helper cell type 2 cytokine secretion and pulmonary eosinophilia during experimental murine respiratory syncytial virus infection. J Exp Med 1997;186:421-32.

47. Johnson TR, Varga SM, Braciale TJ, Graham BS. Vbeta14(+) T cells mediate the vaccine-enhanced disease induced by immunization with respiratory syncytial virus (RSV) G glycoprotein but not with formalininactivated RSV. J Virol 2004;78:8753-60.

48. Johnson TR, Teng MN, Collins PL, Graham BS. Respiratory syncytial virus (RSV) G glycoprotein is not necessary for vaccine-enhanced disease induced by immunization with formalin-inactivated RSV. J Virol 2004;78:6024-32.

49. Yu JR, Kim S, Lee JB, Chang J. Single intranasal immunization with recombinant adenovirus-based vaccine induces protective immunity against respiratory syncytial virus infection. J Virol 2008;82:2350-7.

50. Crowe JE Jr, Firestone CY, Murphy BR. Passively acquired antibodies suppress humoral but not cell-mediated immunity in mice immunized with live attenuated respiratory syncytial virus vaccines. J Immunol 2001;167:3910-8.

51. Pringle CR, Filipiuk AH, Robinson BS, Watt PJ, Higgins P, Tyrrell DA. Immunogenicity and pathogenicity of a triple temperaturesensitive modified respiratory syncytial virus in adult volunteers. Vaccine 1993;11:473-8.

52. Wright PF, Karron RA, Belshe RB, Thompson J, Crowe JE Jr, Boyce TG, et al. Evaluation of a live, cold-passaged, temperature-sensitive, respiratory syncytial virus vaccine candidate in infancy. J Infect Dis 2000;182:133142.

53. Karron RA, Wright PF, Belshe RB, Thumar B, Casey R, Newman F, et al. Identification of a recombinant live attenuated respiratory syncytial virus vaccine candidate that is highly attenuated in infants. J Infect Dis 2005;191:1093-104.

54. Wright PF, Karron RA, Madhi SA, Treanor JJ, King JC, O'Shea A, et al. The interferon antagonist NS2 protein of respiratory syncytial virus is an important virulence determinant for humans. J Infect Dis 2006;193:573-
81.

55. Murphy BR, Sotnikov AV, Lawrence LA, Banks SM, Prince GA. Enhanced pulmonary histopathology is observed in cotton rats immunized with formalin-inactivated respiratory syncytial virus (RSV) or purified F glycoprotein and challenged with RSV 3-6 months after immunization. Vaccine 1990;8:497-502.

56. Murphy BR, Sotnikov A, Paradiso PR, Hildreth SW, Jenson AB, Baggs $\mathrm{RB}$, et al. Immunization of cotton rats with the fusion (F) and large $(\mathrm{G})$ glycoproteins of respiratory syncytial virus (RSV) protects against RSV challenge without potentiating RSV disease. Vaccine 1989;7:533-40.

57. Prince GA, Denamur F, Deschamps M, Garcon N, Prieels JP, Slaoui M, et al. Monophosphoryl lipid A adjuvant reverses a principal histologic parameter of formalin-inactivated respiratory syncytial virus vaccineinduced disease. Vaccine 2001;19:2048-54.

58. Hancock GE, Heers KM, Pryharski KS, Smith JD, Tiberio L. Adjuvants recognized by toll-like receptors inhibit the induction of polarized type 2 T cell responses by natural attachment $(\mathrm{G})$ protein of respiratory syncytial virus. Vaccine 2003;21:4348-58.

59. de Waal L, Power UF, Yuksel S, van Amerongen G, Nguyen TN, Niesters $\mathrm{HG}$, et al. Evaluation of BBG2Na in infant macaques: specific immune responses after vaccination and RSV challenge. Vaccine 2004;22:915-22.

60. Power UF, Nguyen TN, Rietveld E, de Swart RL, Groen J, Osterhaus $\mathrm{AD}$, et al. Safety and immunogenicity of a novel recombinant subunit respiratory syncytial virus vaccine (BBG2Na) in healthy young adults. J Infect Dis 2001;184:1456-60.

61. Durbin AP, Karron RA. Progress in the development of respiratory syncytial virus and parainfluenza virus vaccines. Clin Infect Dis 2003; 37:1668-77.

62. Kohlmann R, Schwannecke S, Tippler B, Ternette N, Temchura $\mathrm{VV}$, Tenbusch $\mathrm{M}$, et al. Protective efficacy and immunogenicity of an adenoviral vector vaccine encoding the codon-optimized $\mathrm{F}$ protein of respiratory syncytial virus. J Virol 2009;83:12601-10.

63. Hsu KH, Lubeck MD, Davis AR, Bhat RA, Selling BH, Bhat BM, et al. Immunogenicity of recombinant adenovirus-respiratory syncytial virus vaccines with adenovirus types 4, 5, and 7 vectors in dogs and a chimpanzee. J Infect Dis 1992;166:769-75.

64. Takimoto T, Hurwitz JL, Zhan X, Krishnamurthy S, Prouser C, Brown $B$, et al. Recombinant Sendai virus as a novel vaccine candidate for respiratory syncytial virus. Viral Immunol 2005;18:255-66.

65. Schmidt AC, McAuliffe JM, Murphy BR, Collins PL. Recombinant bovine/human parainfluenza virus type 3 (B/HPIV3) expressing the respiratory syncytial virus (RSV) G and F proteins can be used to achieve simultaneous mucosal immunization against RSV and HPIV3. J Virol 2001;75:4594-603.

66. Elliott MB, Chen T, Terio NB, Chong SY, Abdullah R, Luckay A, et al. Alphavirus replicon particles encoding the fusion or attachment glycoproteins of respiratory syncytial virus elicit protective immune responses in $\mathrm{BALB} / \mathrm{c}$ mice and functional serum antibodies in rhesus macaques. Vaccine 2007;25:7132-44.

67. Mok H, Lee S, Utley TJ, Shepherd BE, Polosukhin VV, Collier ML, et al. Venezuelan equine encephalitis virus replicon particles encoding respiratory syncytial virus surface glycoproteins induce protective mucosal responses in mice and cotton rats. J Virol 2007;81:13710-22.

68. Cano F, Plotnicky-Gilquin H, Nguyen TN, Liljeqvist S, Samuelson P, Bonnefoy J, et al. Partial protection to respiratory syncytial virus (RSV) elicited in mice by intranasal immunization using live staphylococci with surface-displayed RSV-peptides. Vaccine 2000;18:2743-52. 
69. Martinez-Sobrido L, Gitiban N, Fernandez-Sesma A, Cros J, Mertz SE, Jewell NA, et al. Protection against respiratory syncytial virus by a recombinant Newcastle disease virus vector. J Virol 2006;80:1130-9.

70. Bembridge GP, Rodriguez N, Garcia-Beato R, Nicolson C, Melero JA, Taylor G. Respiratory syncytial virus infection of gene gun vaccinated mice induces Th2-driven pulmonary eosinophilia even in the absence of sensitisation to the fusion (F) or attachment $(\mathrm{G})$ protein. Vaccine 2000; 19:1038-46.

71. Li X, Sambhara S, Li CX, Ewasyshyn M, Parrington M, Caterini J, et al. Protection against respiratory syncytial virus infection by DNA immunization. J Exp Med 1998;188:681-8. 